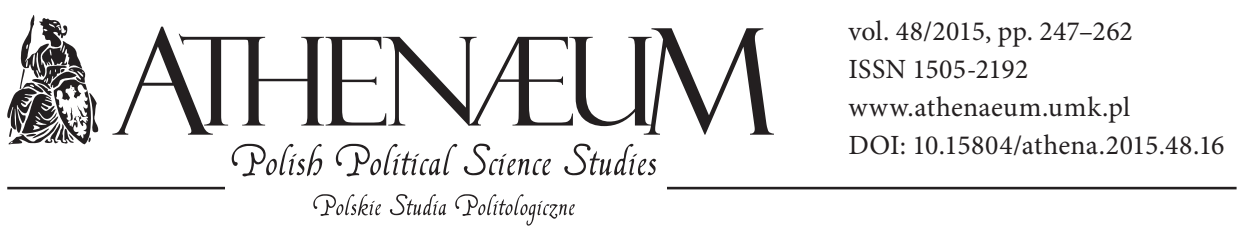

\title{
BROKEN DEMOCRACY, PREDATORY STATE AND NATIONALIST POPULISM
}

\author{
András Bozóki*
}

\begin{abstract}
The main aim of the article is to try to analyze the functioning of Victor Orbán's regime in Hungary in the period from 2010. Analyses oscillate between considering issues such as the development of democracy in Hungary after 1990, history and background of functioning of the Fidesz party, and the course of Orbán's exercise of power. In the paper, the reasons behind the taking of power by Fidesz party were analyzed by taking into account the specifics of Hungarian democratic experience after 1989, processes of state's reforms and economic crises. The article ends with the analysis of five pillars of Victor Orban's policies.
\end{abstract}

\section{KEYWORDS -}

system transition, political parties, Hungary, Victor Orbán, Fidesz, democracy

A new, right-wing government led by Viktor Orbán and his Fidesz party came to power in Hungary on May $2010^{1}$. Since then, it has significantly altered the country's legal, social, and political infrastructure. Its 53\% absolute majority achieved at the ballot boxes meant a two-third majority of seats in Parliament due to the disproportional nature of the electoral system. The Socialist Party

* Central European University, Department of Political Science, Budapest, Hungary.

1 Fidesz (Fiatal Demokraták Szövetsége, Alliance of Young Democrats) was founded in 1988 as a youth, liberal, anti-communist party. Now taking the name "Fidesz - Hungarian Civic Alliance", it is the major conservative-populist party in Hungary. In 2010, it won the elections in being formally in coalition with the Christian Democrats (KDNP), an insignificant political force in itself. To find out more about Fidesz and its ideology (Bozóki 2008: 191-231). 
(MSZP), which was in power between 2002 and 2010, received 19.3\% of the votes only, while a new far right party, Jobbik, made $16.7 \%$, which was interpreted by many as a shocking result. These latter parties remained in opposition together with the green party, Politics Can Be Different (LMP), which received 7.5\% of the votes.

The governing party (Fidesz), enjoying a qualified majority, unanimously voted for the new Constitution. Fidesz has substantially weakened the balance of power, tightened its grip on public and commercial media, restricted people's initiatives, the freedom of the press, social rights, civil liberties, and cut social benefits. It has done away with the principle of power-sharing. Power is concentrated in the hands of the Prime Minister, who did all to centralize his power, personalize politics, create a new clientele dependent on the state, and marginalize the democratic opposition. His notion of a "central arena of power" (mentioned in one of his speeches as early as in 2009) (Orbán 2009) has thus become a reality. The democratic state has been taken over by a small, coherent group of political entrepreneurs, who use the state largely for their own advantage. They offered neoliberal economic policies to the upper classes and ethno-nationalist, populist discourse to the poor. Such an autocratic turn has been unprecedented in the history of the European Union.

Between 1990 and 2010, Hungary was a functioning liberal democracy, when judged against the principles and practices of a modern, Western-type democracy - i.e., the one characterized by competition between political parties, the participation of civil society and respect for civil rights. By 2011, the democratic political order fell into a crisis in Hungary and it has remained so under the attack by the government. The ruling party has succeeded in deconstructing the components of a consensus-based liberal democracy in the name of the majoritarian democracy (Lijphart 1999). However, Orbán went even further - by eliminating independent institutions he transformed this so-called majoritarian democracy into a highly centralized, illiberal regime (Levitsky, Way 2010) ${ }^{2}$. The "majority" today is nothing but an obtuse justification for the ruling political party to further cement its power in a country where the majority of citizens believe that things have gone badly awry. If this so-called "revolutionary" process continues, the result will be semi-democracy, both in the short run and, if they get their way, in the long run as well.

\footnotetext{
2 The term illiberal democracy was first coined by Fareed Zakaria in 1997.
} 
This anti-liberal turn did not emerge out of the blue: it was a direct response to the hectic reforms implemented by previous governments between 2006 and 2010, as well as to the corruption and the economic crisis that ensued. The rise of the Orbán regime has deeper roots as well, the ones that refer to structural, cultural, and political factors that evolved over the period of post-transition Hungary. They include the early institutionalization of a qualified majority consensus, which has obstructed reforms over the past two decades, a plethora of informal practices, ranging from tax evasion to political party financing, which have stalled building a formal democratic institution system; and the serious impact of existing democratic forms on the competition between political parties, which has gradually killed off both the willingness of civic groups to engage in politics and incentives for results-based performance by governments, and has instilled a hatred towards politicians and politics among the population. The survival of the privileged and influential social groups on the other side of transition has also weakened networks of solidarity. Finally, the failure of meaningful economic reforms made the country defenseless against the global financial crisis that exploded in 2008. Taken together, all those factors have produced a perfect political storm.

\section{THE REASONS BEHIND THE ESTABLISHMENT \\ OF THE ORBÁN REGIME. THE EARLY INSTITUTIONALIZATION OF THE COMPULSION TO FORM A CONSENSUS}

During the transition to democracy in Hungary, consensus-building was perceived as a "prestigious" political measure. The "Founding Fathers"3 of democracy at the round-table talks wanted the new, democratic institutional system to be based on as wide a consensus as possible. Meanwhile, the out-going representatives of the old regime wanted to retain their voice in politics. As a result, a complete set of rules was born that sought to strengthen the new democratic order, its stability and its governability, including the qualified

3 The reference here is not to a specific and familiar group of figures but to all those involved in making reforms to the 1949 Hungarian Constitution after 1989. Hungary was the only one of the former Eastern Bloc countries that did not adopt a new constitution - one of many preconditions for the current problems facing the country. 
majority rules, which affected a wide spectrum of policy issues. Apparently, the "Founding Fathers" believed that they could safeguard freedom by increasing the number of decisions that required a qualified majority vote.

These measures created a democracy in which in the period between elections, the ruling governments' power became almost "cemented". It became nearly impossible to remove an incumbent government from the outside. However, this simultaneously made effective governance more difficult. The government in power, due to the high volume of qualified majority rules, had to rely on the opposition to take decisions on basic issues. Paradoxically, the Constitution thus granted both a lot of power and limited political responsibility to the government.

In 1989, the "Founding Fathers" exhibited an ambivalent attitude towards the notion of power. They wanted a strong, democratic form of government based on wide popular support; at the same time, they were averse to the very idea of power itself. To ensure the country's effective governability, the "Founding Fathers" provided excessive safeguards to the political system in comparison to other segments of the society (Bozóki 2002). To put it simply, they overestimated the population's desire for stability. What they did not take into account was the fact that the "illusion of stability" over the long haul could make the system inflexible. The desire for stability is associated not only with the legacy of the era of János Kádár (a communist chief who ruled the country between 1956 and 1988), but also with the hectic, new capitalist system of the past twenty years and the injustices it produced. Democracy in Hungary, in the formal sense, is the most stable in all of Central Europe, because since 1990, all coalition governments have completed their four-year terms of office. However, formal stability has come with a price as the existing regulations have largely prevented the political system from correcting itself. The constitutional system between 1990 and 2010 guaranteed that the government remained in power for the entire cycle, and it thereby ensured the governability of the country. However, it also straight-jacketed the incumbent government through qualified majority rules. Most of these measures, raised to the constitutional level, proved counterproductive. There are additional institutional and structural reasons that explain Hungary's inability to react to external challenges promptly (Zoltán 2013; Kis 2013), and why Hungary became more vulnerable than other countries during the global crisis. Psychological and institutional stability are important aspects. However, it has become clear that treating the idea of stability as a fetish has thwarted the country's development. 


\section{THE PRACTICE OF INFORMALITY}

Throughout its history, Hungary was frequently an occupied country, and this produced a political culture characterized by the prevalence of informal practices and the lack of institutional accountability. Hungarians had learned that they only had to feign that they were obeying the rules imposed upon them by foreign invaders: below the surface, they established a system of informal rules governing the society and culture. Hungarians lived with the duality composed of formal and informal rules, the rules which most often were inherently ambiguous and contradictory. Therefore, Hungarians learned to amble their way around these rules in a conniving fashion, finding loopholes and cutting corners, and this behavioral pattern remains deeply engrained in Hungarian society. They gave the proverbial emperor what the emperor demanded, as it were, but they also evaded taxes where they could. They began to push for individual interests beyond the government by organizing informal networks and small groups. However, they did not form formal organizations, such as unions. Civil society groups and unions helped individuals orient themselves and survive not through collective action, but rather via hush-hush negotiations.

The Kádár regime became a "soft dictatorship" because it was softened by lies. The reason it became more livable is that the system often did not take its own rules seriously. The system of double rules continued to exist, and one had to navigate the maze of formal and informal rules with caution. Under Kádárism, citizens grew accustomed to those procedures that made the dictatorship bearable. For Hungarians, the old system was not nearly as bad as it was for Poles, Czechs, or Romanians. Thus, in 1989, Hungarians broke only with the institutional system of dictatorship, but not with the customs and informal procedures associated with that system (Bozóki, Simon 2006: 146-194). The corrupt nature of the Kádár regime made it easier for people to maneuver within the system, but it does not automatically mean that every system should be corrupt. Moreover, illusions attached to the Kádár regime made it all the more difficult to break with its political culture.

The political sphere assumed increasing power over various segments of society, from the media through the economy, from education through the social sectors to the theater. Election results determine who may become the editor of a newspaper, a school principal, a theater director, or a business leader. In Hungary, in contrast to the standards in normal democracies elsewhere, it is extremely important which party is in power. This means that the financial 
security of many depends on the given political circumstances and the ability of people to position themselves rather than on professional merit and performance. This frustrates all those who wish to deliver in their respective fields professionally. The society has been built on the phenomena of informality and clientelism, so political parties try to deepen their influence through its practice.

The main issues during the past twenty years of Hungary's democracy were not primarily based on the constitutional problems of 1989, but on the ambivalent attitude of the Hungarian society to the formal political institutions. The period following the 1989 Revolution often surprisingly resembles the era before the revolution, because the society again tries to fashion its own informal customs to the new rules.

\section{THE PHENOMENON OF "PARTOCRACY"}

During the second decade of democracy in Hungary, party politics superseded almost all other aspects. The confrontation between the ruling government and its opposition became so intense that it became nearly impossible to solve the country's problems through negotiations, which would have required responsible policy debates and wide-ranging consultations. Fidesz initiated confrontation when it was in power, together with the Independent Smallholder's Party (FKGP) and Hungarian Democratic Forum (MDF) between 1998 and 2002 - as a means of strengthening its initially weaker political position. It was determined to divide the society using the politics of symbolism. Public discourse was based on party allegiance and such discourse could not replace (or at least complement) the necessary policy dialogue or the unbiased popular discourse. The main rival of Fidesz was the Hungarian Socialist Party (MSZP) which came back to power in 2002 and ruled the country until 2010. Out of their eight years in power, they were in coalition with the Alliance of Free Democrats (SZDSZ) for six years. The phenomenon of "partocracy" appeared: what had once been the party-state was replaced by the state of democratic parties".

There are several reasons for the political crisis in Hungary that unfolded after the autumn of 2006, and one of them is the rule of parties. The reforms

\footnotetext{
${ }^{4}$ A very similar phenomenon to the Italian party system in the 1970 s and 1980 s, called partitocrazia.
} 
announced by socialist Prime Minister Ferenc Gyurcsány in 2006 did not take the power of partocracy into account. In a strong democracy, party pluralism develops within the legal framework and is checked by other actors in the system. As such, competition between the parties cannot transform into the dominance of the parties. In Hungary, however, a system was established whereby democracy is almost exclusively exercised by parties, and for this reason, the good of the public becomes secondary to the interests of parties. In the meantime, the rising level of voters' identification with parties and the polarization of the party system created an atmosphere of, what many Hungarians called, a "cold civil war" between the left and right. Behind the sharp rhetorical struggle, a system of interdependence has evolved. This system governs both the relationships within and amongst the parties. One of its most important elements is its policy of rewarding and issuing threats to individual members. Thus, party leaders could maintain both "confidence" as well as "solidarity" with one another, because they knew everything about each other's affairs.

In Hungary, parties assumed civic duties. It was parties that organized "movements"; it was parties that established "public benefit" foundations, "professional" groups and the "citizens" circles. Parties were the ones that delegated representatives to various committees; they sought expert advice of their own experts. Moreover, they had their own journalists writing media reports. In such a system, instead of independent economic experts and market players, there were only think tanks that were sustained by parties and their strawmen. In this system, affairs could only be settled through parties and their clientele. The state was a state of parties, together with its tax authority and security forces.

The particular features of the Hungarian political system - including a collection of candidate nomination slips, a high threshold for entering parliament, the large number of regulatory areas in which there is a requirement to have a qualified majority in order to create laws, the opacity of political party financing, and the privileged position of political party foundations, and so on - facilitated the survival of already-existing parties and made it difficult for new political forces to enter Parliament. Hungarian electoral laws were amongst the least proportional in Europe. That said, a strong democracy does not equate to enshrining the opportunities provided by a multiparty system into law. The Hungarian system was characterized by a highly politicized society, and the excessive sway that political parties had in various areas of public life. This has led to the withering away of the autonomy of certain segments of the society. Furthermore, it has impeded the ability of the entire system for innovation. If a society's progress 
depends on the loyalty to a party rather than on economic performance, people lose interest in producing genuine results.

As the proportion of "partocracy" increases within a democratic regime, corruption becomes an increasing temptation. It is no coincidence that to this day Hungary has no fair party finance law, nor are there any strict rules against the conflict of interests within the decision making bodies controlled by political parties. Corruption does not seem to be an external problem, but an integral part of the system (Magyar 2012; Magyar, Vásárhelyi 2013).

\section{DEMOCRACY OF PRIVILEGES}

The fact that people lost faith in democracy is presumably partly the responsibility of those who form public opinion. After 1989, the roles of the intellectuals changed: their goal was no longer to act as substitutes for democracy that was missing, but to foster dialogue and offer alternatives, contribute to public affairs independently from political parties, participate in public debates, shape values, and raise doubts and fundamental questions.

Only a few journalists faced the fact that several of their colleagues were becoming the mouth pieces of various political and economic actors rather than expressing independent opinions and exposing issues without massaging facts. What should we think of the Hungarian politico-economic elite, which over twenty years has been unable to produce new ideas, behaving at times like a witch doctor, by prescribing the same remedy for every illness? The intellectuals, many of them followers of neoliberal teachings, did not question whether it was true that privatization and deregulation automatically cured the banes of the economy. They did not venture to view the state and the market in a more balanced light (i.e., that the economy and society are interrelated). Political analysts have been stuck in giving their so-called "value-free" comments on the superficial power games of the political elites, and they did not offer meaningful insights on the substance of democracy. Political scientists, if they were to take their profession seriously, should have assessed political phenomena in the social contexts in which they emerged. What is more, they were expected to offer more profound analyses on the relationship between politics and the society than they did. If civil society representatives turned a blind eye to the processes that were destroying democracy, it was no wonder that the politicians they elected themselves did the same. Politicians do not live outside the parameters of a society; 
they only do what this society permits them to do. The intellectual elite tended to forget that democracy could not be solely the affair of politicians, though naturally politicians bore greater responsibility for it than others did.

After 2000, the intellectuals became the guardians of the status quo. It seemed that the patience of the lower classes of society was endless; it also seemed that many of those who had received higher levels of compensation from the state could "get away with" the economic transition. Not only did the memory of the transition become unpopular, but also the entire political class lost its credibility. A significant portion of the intellectuals were responsible for the fact that in the decade following the turn of the millennium, the consolidation of democracy turned into a farcical chase for illusions.

Between 2006 and 2010, the proponents of the ill-conceived reform policies of the ruling former socialist and liberal parties tested the patience of hundreds of thousands of people who were falling into poverty. One particular feature of the process of privatization in Hungary was that after an initial "spontaneous" period, foreign capital had the greatest ownership over the economy. Under these circumstances, the unconditional acceptance of the system by the Left, the discourse of "There Is No Alternative" suggested that its followers were on the side of foreign capital and not of the local Hungarian population. The system did not become popular among the electorate, and as such, this perception sealed the fate of the left-liberal elite. The democratic center did not offer an alternative, for example, with an empathetic, plebeian-type of politicizing to voters. Thus, it paved the way for the extreme right, which sent the following message to hundreds of thousands of uprooted people in its campaign slogans: "Hungary belongs to Hungarians". Nearly by definition, if the policy of the left lacks social solidarity, the values remaining on the side of the road are lifted up by the extreme right based on ethno-nationalist rhetoric. In the battle for economic survival, the ethos of the fight for civil rights faded. In the conditions of neoliberal variant of capitalism, the labor market had already become divided into the "important people" and the "redundant" camps. Furthermore, the technocratic elite often proved incapable of easing social tension. The exclusion from the labor market for extended periods and social marginalization served as the bases for the gain in momentum by radical anti-democratic movements.

5 The rhetoric of "TINA" ("There Is No Alternative") was an inherent part of the dominant neoliberal discourse (Steger, Roy 2010). 


\section{THE FAILURE OF THE REFORMS AND THE ECONOMIC CRISIS}

The political transition of 1989 did not mark the end of the transformation from the old regime. Economic reforms and new institutions were needed, and the new constitutional framework required content. All of this required credible politicians, or people who would swear on their lives that their ideas were not just empty rhetoric that fed the mass media. In the autumn of 2006, when its own credibility was shaken, the Hungarian government submitted a vote of confidence to go ahead with the reforms. Without this vote of confidence, the society did not support the reforms. Against this backdrop, how could reforms be pushed through? Perhaps the reforms would have succeeded, had the socialistliberal government clarified the rules of the game beforehand. At the time, socialist Prime Minister Gyurcsány's proposed anti-corruption legislation was the only reform effort that could have garnered substantial popular support. However, this initiative also failed, because the coalition parties of the time nipped it in the bud.

In Hungary, the terms "reform" and "austerity" became conflated. The political elite should have realized that instead of taking decisions in a coup-like manner - decisions that would affect the livelihoods of many - they should have held a dialogue with stakeholders. They should have been able to explain and convince voters of the anticipated long-term benefits of their policies. The disillusionment that followed was escalated by political scandals. The Prime Minister's speech of May 2006, held in closed circles at Balatonöszöd (the speech was leaked by opponents from within the party in autumn 2006), shocked popular opinion and made it impossible for the reforms to gain popular support. The credibility of the planned reforms was questioned at the core: the very person who had initiated them admitted before his fellow party members that he had earlier not spoken truthfully ${ }^{6}$.

The poor design of the reforms generated intense debates for years to come. Yet none of the debates made it any clearer to voters whether the sacrifices they

\footnotetext{
${ }^{6}$ A recording made at a meeting of Gyurcsány's Socialist Party held on May 26 ${ }^{\text {th }}, 2006$, surfaced in the press in mid-September of that same year. Gyurcsány was heard admitting that "we have obviously been lying for the last one-and-a-half to two years". This resulted in a series of demonstrations against the government. Even though Gyurcsány and the MSZP did not deny the veracity of the recording, the Prime Minister refused to resign (Gyurcsány 2007; Debreczeni 2012).
} 
were making for the reforms would be worthwhile. The government had no vision concerning how healthcare, transportation, or education would improve for citizens; deregulation and pro-market economic policies, inherited from the transition period, were its sole plans. Moreover, communicating the reforms was limited to internal discussions within the political parties. The global financial crisis of 2008 reached Hungary at the time when the government was rapidly losing its domestic political credibility. The result was the nose dive of the Hungarian economy. Only an agreement with the IMF and a quick loan from the Fund was able to save Hungary. Gyurcsány's resignation in the spring of 2009 was the direct result of the economic crisis. His departure led to Gordon Bajnai's one-year "crisis-management" term in office, and, indeed, short-term crisis management presided over long-term reforms. It became obvious to everyone that the socialist and liberal forces behind the government would suffer severe losses during the 2010 general elections.

Over the past twenty years, the consecutive prime ministers often wanted to both implement reforms and please those who opposed reforms. Not one prime minister tried to break with the rule of political parties; instead, each had merely hoped that the "partocracy" would simply accept the reforms. In 2008, voters in a referendum, initiated by Fidesz, rejected the introduction of tuition fees in higher education and the partial co-payment within the healthcare system. In addition, they supported the withdrawal of the already-implemented "visit fees" to be paid to doctors. It thus became apparent that the socialist-liberal coalition had exhausted its political reserves. Thus, the government became weak, burdened by the demands of political governance and the severe lack of confidence that people had in the bureaucracy. Consequently, by 2010, the government had become defenseless against the emerging autocrats. The promise of a "strong state" enabled anti-democratic endeavor to gain popular support.

A democratic state does not rest upon the tips of bayonets: it is strong when it enjoys the trust bestowed upon it by its citizens and weak if this trust is lost. During the 2010 general elections, voters began to see the Hungarian conception of "government" as producing a weak "Weimar" state that could not maintain order. Voters increasingly believed that this weak government had turned Hungary into the country that may be labeled as an "also ran" in the race for democracy in the region. The need for a definitive majority increased, as well as for strong political leadership. Many came to believe the following: "we do not know what is to come, but because what we have now cannot continue, bring on the unknown!". 


\section{THE ORBÁN REGIME AND THE CRISIS OF HUNGARIAN DEMOCRACY}

Despite the serious structural problems described above, for twenty years the Hungarian political system was a liberal democracy characterized by a multiparty system, free elections, representative government, strong opposition, free media, strong and respected institutions that protected the rule of law (i.e., the Constitutional Court and the Ombudsman's Office), and independent courts. Barring a few striking exceptions, humans rights were generally respected, and religious freedoms were not restricted. During the two decades after 1989, incumbent governments had lost every election (with the exception of 2006), the media criticized politicians heavily, democracy was consolidated, and Hungary joined the European Union. The above-discussed problems notwithstanding, until the eve of 2006 Hungary remained a success story of democratic consolidation (Bozóki, Simon 2010: 204-232).

By 2011, however, Hungarian society was forced to realize that the system that had become increasingly freer over the decades had come to a standstill, and it was turning into autocratic direction. This raises the following questions: Is it possible to roll back history? Is it possible to return to a semi-authoritarian regime as a fully-fledged member of the European Union?

\section{CONCEPTUAL UNDERPINNINGS}

Prime Minister Viktor Orbán's policies are based on the pillars of 1. a „central arena of power" (centrális erötér), 2. the rhetoric of "national unification", 3. a change of the elites, 4 . the practice of power politics, and 5. a belief in "revolutionary circumstances".

First, Orbán's notion of a "central arena of power" aimed to eliminate the idea of competition endorsed during the transition to democracy. He wanted to create a system based on the monopolization of the most important elements of political power which are strongly connected with each other through personal networks. In his view, the central area of power should be filled by the politically homogenized culture of the national community which is largely defined on the basis of ethnicity. If out of the three components of liberal democracy - participation, competition, and civil liberties - the option of competition is weakened or removed (through the modification of electoral laws) and the 
institutions that safeguard the rule of law are destroyed, hardly anything is left of democracy. What remains, resonates from the era of state socialism: the "people's democracy". Orbán does not need economic, cultural and political alternatives; he strives to establish his own unitary system of values, which is identified with the national interest. Yet where no alternatives exist, there is no room for liberal democracy either.

Second: almost all of Orbán's important messages are based on the notion of "national unification", which has both symbolic and literal importance. It is used both in foreign and domestic policy. As regards the former, he expressly criticized the Treaty of Trianon that concluded World War I, as well as the legacy of the Communist system and the forces of globalization, both of which he found to be the most important political issues of the day. Orbán suggests that the "nation", understood as an extended family, serves as the bastion that offers protection against these forces. The idea of national unification also maintains that Hungarians living outside Hungary are not minorities, but full members of the Hungarian nation with corresponding rights and privileges. As such, these Hungarians are granted Hungarian citizenship upon request, regardless of where they live, and thus they are also automatically granted voting rights. Orbán believes that the civic right to freedom, membership in the European Union, and being a political ally of the West are only important insofar as they do not contradict the priorities of "national unification". Nonetheless, this policy cannot be described as pure ethno-nationalism, because the cabinet gave equal voting rights to those native Hungarians who live outside Hungary. It was reluctant to grant the same electoral procedures to those who had left Hungary and moved to the West as economic migrants after the accession to the European Union. The government distinguishes between the citizens of the same country when it decides about who the "good" Hungarians are (who deserve full state service) and who are the not-so-good ones who do not deserve the same procedural treatment. Therefore, the rhetoric of "national unification" hides the practice of selective nationalism.

As far as domestic policy is concerned, "national unification" refers to the "system of national cooperation" (a set of "unorthodox" policies combining statism, economic nationalism, crony protectionism and neoliberalism), which has emerged as an alternative to liberal democracy. However, the priorities of Orbán's "system" are not to improve the livelihood of the poor, the marginalized and Roma communities, nor does it encompass the concept of the Republic and the respect for social and cultural diversity. Through his words, Orbán wishes to 
give the impression of uniting the nation by basing its policies on work, home, order, family and the feeling of security (Korkut 2012: 168-177). These basic, conservative concepts are deeply rooted in the more traditional part of the Hungarian society, and the prime minister smartly exploits the emotional impact of these slogans to sell his policy effectively. Yet the reality is that his policies divided society. In his dictionary, the term "people" is not defined as groups of individuals, social classes, or a political community in general, but instead represents a selective ethno-national category justified by history interpreted by him (Bozóki 2013: 346-367).

Third, Fidesz radically changed the administrative elites, by replacing not only top administrative office holders, but also the economic and cultural leaders tied to the experience of previous decades. The first Orbán government (1998-2002) used culture to strengthen its own power. By contrast, the second Orbán administration saw cultural pluralism as a source of unnecessary costs and potential criticism - and it wanted to eliminate both. It did not engage in a cultural battle because it did not want to argue. Instead, it simply changed the administrative elites as broadly and deeply as possible. The aim here was to dismantle the political independence of institutions and to put a group of Orbán loyalists in key positions. Anti-communism was the ideology bolstering this move, which today is no more than a cover for this quest for power. Cultural policies have been replaced by symbolic politics. This endeavor to solidify clientelism sent the message that life outside the "system of national cooperation" was unthinkable.

Fourth, the government's policies were not based on any single ideology, because according to the Prime Minister, the era of ideologies had ended. Viktor Orbán is in no way a conservative politician; he is a nationalist and populist leader who prefers confrontation to compromise. He thinks that competition is always a zero-sum game, in which "either-or" choices cannot be transformed into "more or less" type of solutions. Instead of ideas, Orbán believes in maximizing power, because for him it is not freedom, but a tight-fisted leader who can assure order. Moreover, he believes that he "naturally" embodies the traditional, patriarchal values of hundreds of thousands of rural Hungarians. Those who identify with this mindset are individuals who are servile towards their superiors, but stamp upon their own employees. They also include those individuals who are only obedient towards their superiors if they feel that they are under their watchful gaze. Orbán skillfully attacked banks (most of them are in foreign hands), multinational corporations, foreign media, and the officials of 
the European Union on the grounds of economic nationalism and "sovereign" democracy to earn votes. In the meantime, he introduced a flat tax, restricted the rights of employees, the unemployed and the homeless, divided trade union, nationalized local schools, and eliminated the autonomy of universities. In this situation, "privatization" and "nationalization" do not much differ from each other because the state itself is privatized, i.e. captured by partisan interests. The party-state has been revived in the form of a "family" of power.

Fifth, Orbán interpreted his electoral victory as "revolutionary". This allowed him, with a two-thirds parliamentary majority in hand, to employ exceptional methods by making claims to exceptional circumstances (i.e."revolutionary conditions"). As a result, Orbán deployed warlike, offensive tactics, pushing legislation that quickly and systematically rebuilt the entire public legal system. Fidesz often referred to the ideas espoused in the 1848 Revolution led by Lajos Kossuth (i.e. "revolution and struggle for freedom"), but Fidesz's own "revolutionary struggle" has undermined freedom. In its stead, Fidesz has established a singleparty state, where power rests with the party and the prime minister himself. The state has been captured by a closed group of like-minded political entrepreneurs, a new elite with homogenized attitudes, which uses the state to extract resources for their own particular goals under the aegis of the "common good" and "public interest". Their strategy has been based on the practice of conversion of power, back and forth: political power strengthens their economic power and vice versa. The qualitative majority in the parliament gave an extraordinary opportunity for the ruling party to legislate corruption according to its interests. As it turned out, corruption was not a set of deviant practices, coming from outside the state any longer. On the contrary, it became the leading principle of the state. Corruption, which used to be deviant behavior, became the norm. It is "invisible" because it is the law itself, defended by the "refurbished" Constitutional Court. Paradoxically, from a democratic point of view, the problem is not so much if government people break the law, but it is if they keep it.

While most people wanted to remove Orbán's government from office, they were unable to find a viable political alternative since the opposition has been fragmented for long period of time. There was also no visible group of dissidents existing within Fidesz, who were critical of Orbán and who could offer an alternative vision for the center right. As such, the will of the leader is largely binding and faces no internal limits. 


\section{REFERENCES:}

Bozóki A. (2002). The Roundtable Talks of 1989: The Genesis of Hungarian Democracy. Budapest: CEU Press.

Bozóki A. (2008). Consolidation or Second Revolution? The Emergence of the New Right in Hungary. "Journal of Communist Studies and Transition Politics" 24, No. 2.

Bozóki A. (2013). Családi tüzfészek: a kultúra a szimbolikus politika fogságában. [in:] Magyar polip: A posztkommunista maffiaállam. B. Magyar, J. Vásárhelyi (eds.). Budapest: Noran Libro.

Bozóki A., Simon E. (2006). Formal Institutions and Informal Politics in Hungary. [in:] Formal Institutions and Informal Politics in Central and Eastern Europe. G. Meyer (ed.). Opladen: Barbara Budrich Publishers.

Bozóki A., Simon E. (2010). Hungary Since 1989. [in:] Central and Southeast European Politics since 1989. S.P. Ramet (ed.). Cambridge: Cambridge University Press.

Debreczeni J. (2012). A 2006-os ősz. Debrecen: De. Hukönyv.

Gyurcsány F. (2007). A teljes balatonőszödi szöveg. "Népszabadság” May 26.

Kis J. (2013). Az összetorlódott idő. Bratislava: Kalligram.

Korkut U. (2012). Liberalization Challenges in Hungary: Elitism, Progressivism, and Populism. New York: Palgrave Macmillan.

Levitsky S., Way L. (2010). Competitive Authoritarianism: Hybrid Regimes After the Cold War. New York: Cambridge University Press.

Lijphart A. (1999). Patterns of Democracy: Government Forms and Performance in Thirty-six Countries. New Haven: Yale University Press.

Magyar B. (2012). Az új nemzeti középosztály: szolgáló nemesek és udvari beszállítók rendje. "Élet és Irodalom” 10.

Magyar B., Vásárhelyi J. (2013). Magyar polip: a posztkommunista maffiaállam. Budapest: Noran Libro.

Orbán V. (2009). Speech in Kötcse. [online] www.nagyítás.hu; [accessed 20.10.2014].

Steger B., Roy R.K. (2010). Neoliberalism: A Very Short Introduction. Oxford: Oxford University Press.

Zakaria F. (2003). The Future of Freedom: Illiberal Democracy at Home and Abroad. New York: W.W. Norton.

Zoltán A. (2013). Miért Magyarország? “HVG”, June 13. 